\title{
Effects of Multi-Scale Climate Change on The Distribution of Invasive Insect Populations and The Development of Ecological Services: A Case Study of Zeugodacus Cucurbitae (Coquillett)
}

\section{Yuyang Lian}

Hainan University

Aqiang Wang

Hainan University

Bei Zeng

Hainan University

Heming Yang

Hainan University

Jinlei Li

Hainan University

Sihua Peng

Hainan University

Shihao Zhou ( $\nabla$ zsh88200939@126.com )

Hainan University https://orcid.org/0000-0002-5644-6998

\section{Research Article}

Keywords: climate change, Zeugodacus cucurbitae (Coquillett), distribution, population, ecosystem services

Posted Date: September 3rd, 2021

DOl: https://doi.org/10.21203/rs.3.rs-845374/v1

License: (c) (i) This work is licensed under a Creative Commons Attribution 4.0 International License. Read Full License 


\section{Abstract}

In order to clarify the effects of multi-scale climate change on the population distribution and ecological service function of Z.cucurbitae, this paper analyzed its suitable distribution area Z.cucurbitae in a wide scale using the MaxEnt ecological model. Z.cucurbitae were exposed under short-term high temperatures of $33^{\circ} \mathrm{C}, 37^{\circ} \mathrm{C}, 41^{\circ} \mathrm{C}$ and $45^{\circ} \mathrm{C}$ for $1 \mathrm{~h}$, which were set based on recorded high temperatures in the field. The effects of these temperatures on development and reproduction of Z.cucurbitae in successive three generations were evaluated. The results showed that under current climatic conditions, the suitable regions of Z.cucurbitae included most of South America, southeast North America, sub-Saharan Africa, part of Oceania and southern coastal areas of Asia. Under two carbon emissions scenarios (RCP4.5 and RCP8.5), the suitable area of Z.cucurbitae will expand compared to that under current environment and this expansion will generally be northwards. Short-term high temperature was not conducive to the development and reproduction of Z.cucurbitae. The $\mathrm{F}_{1}$ Z.cucurbitae exposed under $45^{\circ} \mathrm{C}$ for $1 \mathrm{~h}$ stimulated its oviposition, and the offspring can still continue the population. When the offspring were continuously exposed to short-term high temperature until the $F_{3}$, they could not oviposit. In the context of climate change, both large-scale and small-scale changes will affect the distribution and population breeding of Z.cucurbitae, which will lead to local sudden outbreak or migration disaster. Therefore, a broad-scale distribution analysis of all populations as a whole will result in a narrow ecological niche and may fail to predict the effects of some local small-scale habitat changes.

\section{Introduction}

Climate change is one of the key issues of global environmental change. In the face of climate change, species either tolerate or adapt, or migrate or perish (Pecl et al. 2017). The response forms of species also affect ecological service function by way of biodiversity change. With global warming, the occurrence time, intensity and frequency of high temperature and extreme high temperature events are increasing. Climate change affects the distribution and population development of global organisms, and then affects biodiversity (Stefan and Dim 2011; IPCC 2013). Insects, as typical poikilotherm, are extremely sensitive to climate change. Their ontogeny and population development rates are closely related to climate change, making them ideal materials for studying climate change-species- ecological service function (Bale et al. 2002; Du et al. 2007; Chen and Ma 2010; Ma et al. 2016).

Zeugodacus cucurbitae (Coquillett) are important multi-host, widely distributed and harmful invasive pest of fruit and vegetable crops (Dhillon et al. 2005). Climate change has an important impact on the distribution and population development of Z.cucurbitae (Coquillett). Current studies mostly focus on the effects of small-scale and long-term climate conditions on the population development of Z.cucurbitae (Coquillett) (Yuan et al. 2005; Li et al. 2008; Wei et al. 2011). On the large-scale context, climate change affects the distribution pattern of pests. On the small-scale, pests usually respond to changes in environmental conditions such as niche temperature rather than long-term constant conditions, and pests can produce responses different from the traditional long-term constant conditions (Ma et al. 2016). Several studies have shown that short-term high temperature had special effects on insects.. For 
example, exposure of Sitobion avenae (Fabricius) to $45^{\circ} \mathrm{C}$ for 40 s, did not result in its mortality (Yang 2013). Exposure of Ophraella Communa to short-term high temperature treatment stimulated oviposition, but egg hatching rate decreased (Zhou et al. 2011; Chen et al. 2018). The copulation and oviposition of Z.cucurbitae (Coquillett) were stimulated after being treated at $45^{\circ} \mathrm{C}$ for $1 \mathrm{~h}$ (Zhou 2016).

Under the background of global climate change, insects can adjust and mitigate the impact of smallscale climate change through phenotypic adaptation and rapid evolutionary response, and thus affect their ecological service function (Bale et al. 2002). Understanding the plasticity of insects and their ability to regulate their own temperature is critical to developing strategies for the conservation of ecological services function (Van et al. 2019). Climate temperature change has the greatest impact on insect growth, development and reproduction, among which high temperature is one of the most important environmental factors as it affects the growth, development and reproduction of insects including Z.cucurbitae (Coquillett). For example, short-term high temperature on a small scale can stimulate Z.cucurbitae (Coquillett) to produce "toxic excitatory effect" (Zhou 2016). "Toxic excitatory effect" is a special heat response strategy produced by pests under appropriate heat intensity, and it is also considered as a survival strategy against heat stress (short-term or long-term variable heat) (Villalpando et al. 2008; Zhang et al. 2013; Ma et al. 2016). Contemporary adults of Z.cucurbitae (Coquillett) increased their spawning quantity after being exposed to short-term high temperature for $1 \mathrm{~h}$, thus maintaining population development (Zhou 2016). Additionally, these effects can also be experienced by insect offspring through maternal transmission (Hoffmann and Sgrò 2011). Most studies have focused on the effects of high temperature on Z.cucurbitae (Coquillett) (Jiang 2005; Yuan et al. 2005; Zhou 2016; Zeng et al. 2018; Gu et al. 2020). However, the effects of high temperature on the growth, development and survival of successive generations of Z.cucurbitae (Coquillett) in small-scale habitats Z.cucurbitae (Coquillett) also need to be known. In the context of climate change, the large- and small-scale effects of climate change on Z.cucurbitae (Coquillett) need to be studied in combination.

In this study, based on the MaxEnt ecological model, we analyzed the potential suitable distribution range and pattern of Z.cucurbitae (Coquillett) under climate change under the current and future climatic conditions using the environmental variable data under three different $\mathrm{CO}_{2}$ emission concentrations (RCP2.6, RCP4.5 and RCP8.5). The influence of different climatic conditions on its distribution pattern was determined and the trend of invasion and expansion Z.cucurbitae (Coquillett) were predicted. In addition, based on the results of studies on the effects of different heat stress on the defense and reproductive strategies of contemporary adult Z.cucurbitae (Coquillett), the reproducibility of the "toxic excitatory effect" of short-term high temperature on Z.cucurbitae (Coquillett) in different generations was discussed to clarify whether the "maternal effect" appeared.The effects of short-time high temperature in small scale on growth, development and reproduction of Z.cucurbitae (Coquillett) in successive generations were evaluated. The results are as follows.

\section{Materials And Methods}


Analysis of suitable regions of Z.cucurbitae (Coquillett) under the background of broad-scale climate change

\section{Collection of geographical distribution data}

The global distribution of Z.cucurbitae (Coquillett) was Z.cucurbitae (Coquillett) extracted from published data on occurrence. The coordinates of these locations Z.cucurbitae (Coquillett) were extracted from the Google map open platform. The data format of sampling points was decimal, and finally a total of 70 Z.cucurbitae (Coquillett) distribution points were selected for model construction and prediction of suitable regions.

\section{Acquisition and screening of climate data}

Data on 19 environmental factors were used in this study and were obtained from the WordClim database (https: // www. wordclim.org) (Table 1). The data was published in 2005 and covers the period 19601990. The accuracy of the data was 2.5 arc-minutes. The tangential method in MaxEnt (version 3.4.1) was used to rank the importance of environmental factors. The correlation analysis to determine the important environmental factors were performed in SPSS (version 26.0). Only one representative environmental factor was retained when the absolute value of the correlation between two ecological factors was greater than or equal to 0.8 (Sunil et al. 2014; Rozhnov et al. 2021). Finally, 10 environmental factors were judged as important for the distribution of Z.cucurbitae (Coquillett), which were annual mean temperature (Bio1), monthly mean diurnal temperature difference (Bio2), ratio of diurnal temperature difference to annual temperature difference (Bio3), mean temperature in the wettest quarter (Bio8), mean temperature in the warmest quarter (Bio10), precipitation in the wettest month (Bio13), precipitation in the driest month (Bio14), seasonal variation coefficient of precipitation (Bio15), precipitation in the warmest quarter (Bio18) and precipitation in the coldest season (Bio19). These environmental data were used to predict the suitable regions for Z.cucurbitae (Coquillett) under three greenhouse gas emission scenarios (RCP2.6, RCP4.5 and RCP8.5) in a future climate condition Z.cucurbitae (Coquillett) (2041-2060). The future climate data used in the study is from the 2050s (2041-2060). The climate variable data are taken from three of the four GHG emission scenarios (RCP2.6, RCP4.5 and RCP8.5) under the Common Climate Model (CCSM4) proposed in the IPPC-AR5 Fifth Assessment Report.Their distribution represents three scenarios of low, medium and high greenhouse gas emissions (He et al. 2020). 
Table 1

Climate and environment variables

\begin{tabular}{|ll|}
\hline Variables & Climatic factors \\
\hline Bio1 & Annual average temperature \\
Bio3 & Monthly mean temperature difference between day and night \\
Bio4 & Ratio of diurnal temperature difference to annual temperature difference \\
Bio5 & Measonal variance of temperature \\
Bio6 & Lowest temperature in the coldest month \\
Bio7 & Annual variation range of temperature \\
Bio8 & Average temperature in the wettest quarter \\
Bio9 & Average temperature in the driest quarter \\
Bio10 & Average temperature of the warmest quarter \\
Bio11 & Average temperature in the coldest quarter \\
Bio12 & Average annual precipitation \\
Bio13 & Precipitation in the wettest month \\
Bio14 & Precipitation in the driest month \\
Bio15 & Seasonal variation coefficient of precipitation \\
Bio16 & Precipitation in the wettest quarter \\
Bio17 & Precipitation in the driest quarter \\
Bio18 & Precipitation in the warmest quarter \\
Bio19 & Precipitation in the coldest quarter \\
\hline
\end{tabular}

\section{Model construction and evaluation}

Based on the location data and the above 10 important environmental factors screened by MaxEnt, three sets of future climate and environmental data were imported for prediction, and the prediction results were visualized in ArcMap. After beautifying the figure, the prediction map of the suitable area of Z.cucurbitae (Coquillett) was derived. In this study, the area under the receiver operating characteristic curve (AUC) was used as an index to measure the accuracy of model prediction (Jorge 2016). A range of $0.5-1,0.5$ corresponded to a completely random prediction; $0.5-0.7$ indicate, a poor accuracy of the prediction result; $0.7-0.9$ indicate, a moderate accuracy of the prediction result; $>0.9$ indicat, a very high accuracy of the prediction result. A proportion of $75 \%$ of the coordinate data was randomly selected as the training set of the experiment, and the remaining $25 \%$ of the coordinate data was used as the test set. 
ROC curve was drawn and AUC value was calculated as the standard to test the accuracy of the prediction results of the model.

Evaluation of the effects of temperature changes in small-scale habitats on the population development of Z.cucurbitae (Coquillett)

\section{Pest source for testing and pest management}

The insects for this study were collected from balsam pear fields $\left(109^{\circ} 29^{2} \mathrm{e}, 19^{\circ} 30^{\prime} \mathrm{N}\right)$ in Nada Town, Danzhou City, Hainan Province, China. Larvae were then fed on artificial diet in the laboratory for breeding. The formula for the diet included $1000 \mathrm{~g}$ of pumpkin. $1000 \mathrm{~g}$ of corn flour, $200 \mathrm{~g}$ of yeast powder, $200 \mathrm{~g}$ of sucrose, $6 \mathrm{~g}$ of sodium benzoate, $8 \mathrm{ml}$ of concentrated hydrochloric acid and $1000 \mathrm{ml}$ of water. Adults were fed on a diet made up of sucrose and yeast powder $(\mathrm{W}: \mathrm{W})$ in equal proportion. The average indoor temperature was $25 \pm 1^{\circ} \mathrm{C}, 70 \pm 5 \% \mathrm{RH}, 14 \mathrm{~L}: 10$ days, and a stable laboratory temperature sensitive population was established. In this study, the short-time high temperature treatment insects were all newly emerged adults of Z.cucurbitae (Coquillett).

\section{Test reagents and materials}

The reagents used in this study, such as yeast powder, corn meal, sodium benzoate, concentrated hydrochloric acid and sucrose, were all purchased from Hainan Qingfeng Biotechnology Co., LTD., and the pumpkins were purchased from the surrounding farmers' markets.

\section{Setting of short-term high temperature treatment for niche}

The optimum temperature for Z.cucurbitae (Coquillett) was $25-30^{\circ} \mathrm{C}$ (Wei et al., 2011). External temperatures $>30^{\circ} \mathrm{C}$, were considered as high temperature range. The newly emerged adults of the $F_{1}-F_{3}$ generations of Z.cucurbitae (Coquillett) were exposed under $25^{\circ} \mathrm{C}(\mathrm{CK}), 33^{\circ} \mathrm{C}, 37^{\circ} \mathrm{C}, 41^{\circ} \mathrm{C}$ and $45^{\circ} \mathrm{C}$ independently for $1 \mathrm{hr}$ in an artificial climate chamber.

Effects of short-term high temperature on oviposition ability and egg development of Z.cucurbitae (Coquillett) in successive generations

Twelve males and females of newly emerged adults from each generation were released together in cages, which was supplied with water and artificial diet for adults and pumpkin flakes for laying eggs. At the end of the exposure to the high temperature treatments, the total spawning quantity (grain), spawning quantity per female (grain), daily spawning quantity per female (grain), pre-spawning period (D), spawning days (D) and egg hatching rate (\%) were observed and recorded every day. Each cage of the 12 pairs was considered as 1 replicate and 6 replicates were set up for under each treatment.

Effects of short-term high temperature on the survival and development of successive generations of Z.cucurbitae (Coquillett)

The survival rate (\%) and longevity (d) of adults in each group and each generation were recorded after the end of short-term high temperature treatment. The survival rate and overall longevity were counted 
separately from males and females. 12 pairs were divided into 1 replicate with 6 replicates in each group.The larvae of each generation were randomly selected and divided into 6 groups with 120 larvae in each group and 1 replicate in each group. Pupation rate (\%), pupa weight (g), eclosion rate (\%) and sex ratio were observed and recorded.

\section{Statistical analysis of data}

Descriptive statistics and analysis of the data were performed with Excel 2013 and SPSS 20.0 respectively. The recorded indices were: oviposition per female (grain): total oviposition/12, oviposition per female per day (grain): oviposition per female/oviposition period; pre-spawning (d): total time of spawning /12; spawning days (d): spawning period /12; egg hatching rate (\%): number of eggs hatched/total number of eggs laid $\times 100$;survival rate (\%): number of viable insects /12×100; life span (d): total survival time $/ 12$, in which the survival rate and total life span were counted separately for male and female; pupation rate (\%): pupation number /120×100; eclosion rate (\%): eclosion number/total pupa number $\times 100$; sex ratio: female/male.

\section{Results}

Analysis of the suitability of Z.cucurbitae (Coquillett) under broad-scale climate change

\section{Evaluation results of suitability analysis model}

The model evaluation results showed that the AUC values of each prediction results were above 0.96 (Table 2), indicating a high accuracy of the prediction results (Li et al. 2012; Wang et al. 2019). In order to further verify the accuracy of the model, 50 of the location data were randomly selected to be used as the modeling data points for the MaxEnt model. The remaining 20 were used for model evaluation Z.cucurbitae (Coquillett). The results of the model evaluation showed that 50 location points including the 20 used as test data fitted the appropriate area of the Z.cucurbitae (Coquillett). This further proved the accuracy of the prediction results of the model.

Table 2

Area under the receiver operating characteristic curve

\begin{tabular}{|lllll|}
\hline AUC & Current & RCP2.6 & 2050s & RCP8.5 \\
& & & RCP4.5 & \\
\hline Training data & 0.966 & 0.967 & 0.964 & 0.968 \\
Testing data & 0.960 & 0.964 & 0.965 & 0.961 \\
\hline
\end{tabular}

Analysis of suitable regions of Z.cucurbitae (Coquillett) under current climatic conditions

Based on the results of the MaxEnt model mentioned above, we analyzed the suitable regions of Z.cucurbitae (Coquillett) under current climatic conditions. The results showed that the most suitable areas for the development of Z.cucurbitae (Coquillett) were the tropical and subtropical regions, 
Z.cucurbitae (Coquillett) except extremely arid and hot desert areas such as the Sahara. Most of South America, southeastern Parts of North America, sub-Saharan Africa, parts of Oceania, and southern coastal areas of Asia all have favorable climatic conditions for the Z.cucurbitae (Coquillett) (Fig. 1). Among them, the medium and high suitable areas Z.cucurbitae (Coquillett) were concentrated in southern China, Myanmar, Thailand, India, Vietnam, northeast Pakistan, Japan, South Korea, Indonesia, northern Australia, eastern Tanzania, Cuba, eastern Mexico and southeastern coastal areas of the United States.

\section{Prediction of future suitability zones of Z.cucurbitae (Coquillett) based on climate change with three different carbon emissions}

Three different carbon emission scenarios (RCP2.6, RCP4.5 and RCP8.5) were used to predict the suitability zones Z.cucurbitae (Coquillett) for Z.cucurbitae (Coquillett) worldwide. By 2050 and under RCP2.6, future conditions will be stable, which will produce a relatively stable habitat range for Z.cucurbitae (Coquillett) (Fig. 2A). However, under RCP4.5 (Fig. 2B) and RCP8.5 (Fig. 2C), the total area of the suitable area of Z.cucurbitae (Coquillett) will increase, compared to current environment and the expansion of this suitable area Z.cucurbitae (Coquillett) will be northwards. For example, under RCP4.5 and RCP8.5, Jilin and Heilongjiang provinces in China changed from unsuitable areas to low-suitability areas. Also, suitable areas for the survival of Z.cucurbitae (Coquillett) appeared in the southeastern coastal areas of Russia. In addition, low suitability zones for Z.cucurbitae (Coquillett) were also located in northern Iran, Iraq and southern Turkey. We speculate that Z.cucurbitae (Coquillett) will pose serious threats in most areas of the tropical, subtropical and warm regions of the world in future climate conditions, and even areas around the Mediterranean may become more hospitable to Z.cucurbitae (Coquillett) populations.

Effects of short-term high temperature in small-scale habitat on growth, development and reproduction of Z.cucurbitae (Coquillett)

\section{Effects of short-term high temperature on oviposition and egg development of Z.cucurbitae (Coquillett)( $F_{1}$ generation)}

The effects of short-time high temperature on oviposition and egg development of Z.cucurbitae (Coquillett) ( $F_{1}$ generation) are shown in Table 3 . The total spawning quantity decreased with increase in temperature. However, the total spawning quantity, daily spawning quantity and single female spawning quantity increased at $45^{\circ} \mathrm{C}$ for $1 \mathrm{~h}$, which were 8411 eggs, 91 eggs and 701 eggs, respectively. These were the highest among all treatments, and showed significant difference with $\mathrm{CK}_{1}$. The early stage of oviposition was shortened with increase in temperature. The shortest stage of oviposition at $45^{\circ} \mathrm{C}$ was only 6 days, and $\mathrm{CK}_{1}$ was 11.2 days. The number of spawning days decreased gradually with increase in temperature. It was 92.7 days at $45^{\circ} \mathrm{C}$ and 159.8 days at $\mathrm{CK}_{1}$. The hatchability of eggs decreased with increase in temperature. The lowest of $31.9 \%$ was recorded at $45^{\circ} \mathrm{C}$ and $90.6 \%$ at $\mathrm{CK}_{1}$. 
Table 3

Effects of short term high temperature on oviposition and egg development of Z.cucurbitae (Coquillett) $\left(\mathrm{F}_{1}\right.$ generation)

\begin{tabular}{|c|c|c|c|c|c|c|}
\hline $\begin{array}{l}\text { Dispose } \\
\text { Index }\end{array}$ & $\begin{array}{l}\text { Total amount } \\
\text { of spawning }\end{array}$ & $\begin{array}{l}\text { Spawning a } \\
\text { quantity }\end{array}$ & $\begin{array}{l}\text { Number of } \\
\text { eggs per } \\
\text { female }\end{array}$ & $\begin{array}{l}\text { Lay } \\
\text { eggs } \\
\text { early }\end{array}$ & $\begin{array}{l}\text { Spawning } \\
\text { days }\end{array}$ & $\begin{array}{l}\text { Egg } \\
\text { hatchability }\end{array}$ \\
\hline $\begin{array}{l}33^{\circ} \mathrm{C} \\
-1 \mathrm{~h}\end{array}$ & $7227 \pm 42.3 c$ & $57 \pm 1.6 b c$ & $602 \pm 3.5 c$ & $\begin{array}{l}10 \pm \\
0.3 a b\end{array}$ & $\begin{array}{l}128.2 \pm \\
4.3 \mathrm{~b}\end{array}$ & $\begin{array}{l}81.5 \pm \\
0.0052 b\end{array}$ \\
\hline $\begin{array}{l}37^{\circ} \mathrm{C} \\
-1 \mathrm{~h}\end{array}$ & $6735 \pm 50.7 d$ & $57 \pm 2.4 b$ & $561 \pm 4.2 d$ & $\begin{array}{l}9 \pm \\
0.3 \mathrm{bc}\end{array}$ & $\begin{array}{l}118.7 \pm \\
5.5 \mathrm{bc}\end{array}$ & $\begin{array}{l}75.7 \pm \\
0.0059 c\end{array}$ \\
\hline $\begin{array}{l}41^{\circ} \mathrm{C} \\
-1 \mathrm{~h}\end{array}$ & $6582 \pm 49.6 d$ & $60 \pm 1.9 b$ & $548 \pm 4.1 d$ & $\begin{array}{l}8.7 \pm \\
0.3 c\end{array}$ & $\begin{array}{l}109.5 \pm \\
3.0 \mathrm{~cd}\end{array}$ & $\begin{array}{l}52.6 \pm \\
0.0024 d\end{array}$ \\
\hline $\begin{array}{l}45^{\circ} \mathrm{C} \\
-1 \mathrm{~h}\end{array}$ & $8411 \pm 43.1 \mathrm{a}$ & $91 \pm 1.6 a$ & $701 \pm 3.6 a$ & $6 \pm 0.3 d$ & $\begin{array}{l}92.7 \pm \\
2.6 \mathrm{dc}\end{array}$ & $\begin{array}{l}31.9 \pm \\
0.0038 \mathrm{e}\end{array}$ \\
\hline $\mathrm{CK}_{1}$ & $7766 \pm 44.1 b$ & $49 \pm 2.4 c$ & $647 \pm 3.7 b$ & $\begin{array}{l}11.2 \pm \\
0.3 a\end{array}$ & $\begin{array}{l}159.8 \pm \\
5.2 a\end{array}$ & $\begin{array}{l}90.6 \pm \\
0.0026 a\end{array}$ \\
\hline \multicolumn{7}{|c|}{$\begin{array}{l}\text { Note: Data were mean } \pm \text { SE. The data in the same column followed by different lowercase letters } \\
\text { indicated significant difference at the level of } 0.05 \text { (Duncan's new complex range method). The same } \\
\text { bellow. }\end{array}$} \\
\hline
\end{tabular}

Effects of short-time high temperature on oviposition and egg development of Z.cucurbitae (Coquillett) ( $F_{2}$ generation)

The effects of short-time high temperature on oviposition and egg development of Z.cucurbitae (Coquillett) $\left(\mathrm{F}_{2}\right.$ generation) are shown in Table 4. The total oviposition, daily oviposition and single female oviposition decreased with increase in temperature. the lowest values of 471 eggs, 17 eggs and 39 eggs, respectively, were recorded under a temperature of $45^{\circ} \mathrm{C}$ for $1 \mathrm{~h}$, which was significantly different from that obtained under $\mathrm{CK}_{2}$. The results showed that short-term high temperature treatment for two generations had a negative influence on oviposition. The early stage of oviposition was still shortened with increase in temperature, and the shortest value of 7.2 days was recorded at $45^{\circ} \mathrm{C}$ while that recorded under $\mathrm{CK}_{2}$ was 11 days. Z.cucurbitae (Coquillett) This high temperature may have promoted the rapid maturation and discharge of eggs, so as to maintain the stability of the population and also to avoid the harm that may be caused by this high temperature. The spawning days also showed a gradual decrease with increase in temperature, and the minimum value of 30 days was recorded at $45^{\circ} \mathrm{C}$, and 152.3 days at $\mathrm{CK}_{2}$, the hatchability of eggs also decreased continuously with increase in temperature. The lowest value of $13.6 \%$ was recorded at $45^{\circ} \mathrm{C}$, and $91.3 \%$ at $\mathrm{CK}_{2}$. It indicated that increase in temperature resulted in a shorter duration for egg laying but a decrease in the hatchability of eggs. 
Table 4

Effects of short term high temperature on oviposition and egg development of $Z$. cucurbitae (Coquillett) $\left(F_{2}\right.$ generation)

\begin{tabular}{|c|c|c|c|c|c|c|}
\hline $\begin{array}{l}\text { Dispose } \\
\text { Index }\end{array}$ & $\begin{array}{l}\text { Total amount } \\
\text { of spawning }\end{array}$ & $\begin{array}{l}\text { Spawning a } \\
\text { quantity }\end{array}$ & $\begin{array}{l}\text { Number of } \\
\text { eggs per } \\
\text { female }\end{array}$ & $\begin{array}{l}\text { Lay } \\
\text { eggs } \\
\text { early }\end{array}$ & $\begin{array}{l}\text { Spawning } \\
\text { days }\end{array}$ & $\begin{array}{l}\text { Egg } \\
\text { hatchability }\end{array}$ \\
\hline $\begin{array}{l}33^{\circ} \mathrm{C} \\
-1 \mathrm{~h}\end{array}$ & $6140 \pm 35.9 b$ & $50 \pm 1 a$ & $512 \pm 3 b$ & $\begin{array}{l}10.2 \pm \\
0.3 a b\end{array}$ & $\begin{array}{l}124 \pm \\
2.9 b\end{array}$ & $\begin{array}{l}67.6 \pm \\
0.0049 b\end{array}$ \\
\hline $\begin{array}{l}37^{\circ} \mathrm{C} \\
-1 \mathrm{~h}\end{array}$ & $5391 \pm 33.1 c$ & $49 \pm 1.8 a$ & $449 \pm 2.8 c$ & $\begin{array}{l}9.3 \pm \\
0.3 \mathrm{~b}\end{array}$ & $\begin{array}{l}110.5 \pm \\
3.9 c\end{array}$ & $\begin{array}{l}51 \pm \\
0.0048 \mathrm{c}\end{array}$ \\
\hline $\begin{array}{l}41^{\circ} \mathrm{C} \\
-1 \mathrm{~h}\end{array}$ & $3324 \pm 35.3 d$ & $38 \pm 0.6 b$ & $277 \pm 2.9 \mathrm{~d}$ & $\begin{array}{l}8.8 \pm \\
0.4 \mathrm{~b}\end{array}$ & $\begin{array}{l}88.5 \pm \\
1.9 \mathrm{~d}\end{array}$ & $\begin{array}{l}33.9 \pm \\
0.007 \mathrm{~d}\end{array}$ \\
\hline $\begin{array}{l}45^{\circ} \mathrm{C} \\
-1 \mathrm{~h}\end{array}$ & $471 \pm 11 e$ & $17 \pm 1.6 c$ & $39 \pm 0.9 e$ & $\begin{array}{l}7.2 \pm \\
0.4 c\end{array}$ & $30 \pm 3.2 e$ & $\begin{array}{l}13.6 \pm \\
0.0031 \mathrm{e}\end{array}$ \\
\hline $\mathrm{CK}_{2}$ & $7744 \pm 30.2 a$ & $51 \pm 1.5 a$ & $645 \pm 2.5 a$ & $\begin{array}{l}11 \pm \\
0.4 a\end{array}$ & $\begin{array}{l}152.3 \pm \\
3.9 a\end{array}$ & $\begin{array}{l}91.3 \pm \\
0.0037 a\end{array}$ \\
\hline
\end{tabular}

Effects of short-term high temperature on oviposition and egg development of Z.cucurbitae (Coquillett) ( $F_{3}$ generation)

The effects of short-time high temperature on oviposition and egg development of Z.cucurbitae (Coquillett) ( $F_{3}$ generation) are shown in Table 5 . The total oviposition, daily oviposition and single female oviposition all decreased with increase in temperature. No eggs were laid under exposure to temperature of $45^{\circ} \mathrm{C}$ for $1 \mathrm{~h}$, which was significantly different from $\mathrm{CK}_{3}$. This indicated that the oviposition was negatively affected by exposure to multiple short-term high temperatures. The prophase of oviposition lengthened with increase in temperature and the longest period of 14.2 days was recorded at $41^{\circ} \mathrm{C}$, and 10.8 days at $\mathrm{CK}_{3}$. This indicated that three consecutive three generations of short-time high temperature treatments were not beneficial for the development of eggs. The number of spawning days decreased gradually with increase in temperature, and the shortest day 69.3 days was recorded at $41^{\circ} \mathrm{C}$ and 155 days at $\mathrm{CK}_{3}$. The hatchability of eggs decreased with increase temperature. It was only $21 \%$ at $41^{\circ} \mathrm{C}$ and $90.7 \%$ at $\mathrm{CK}_{3}$. 
Table 5

Effects of short term high temperature on oviposition and egg development of $Z$. cucurbitae (Coquillett) $\left(\mathrm{F}_{3}\right.$ generation)

\begin{tabular}{|c|c|c|c|c|c|c|}
\hline $\begin{array}{l}\text { Dispose } \\
\text { Index }\end{array}$ & $\begin{array}{l}\text { Total amount } \\
\text { of spawning }\end{array}$ & $\begin{array}{l}\text { Spawning a } \\
\text { quantity }\end{array}$ & $\begin{array}{l}\text { Number of } \\
\text { eggs per } \\
\text { female }\end{array}$ & $\begin{array}{l}\text { Lay } \\
\text { eggs } \\
\text { early }\end{array}$ & $\begin{array}{l}\text { Spawning } \\
\text { days }\end{array}$ & $\begin{array}{l}\text { Egg } \\
\text { hatchability }\end{array}$ \\
\hline $\begin{array}{l}33^{\circ} \mathrm{C} \\
-1 \mathrm{~h}\end{array}$ & $6075 \pm 34.2 b$ & $50 \pm 1 a$ & $506 \pm 2.8 b$ & $\begin{array}{l}11.3 \pm \\
0.2 \mathrm{bc}\end{array}$ & $\begin{array}{l}121.2 \pm \\
2.1 \mathrm{~b}\end{array}$ & $\begin{array}{l}59.7 \pm \\
0.0048 b\end{array}$ \\
\hline $\begin{array}{l}37^{\circ} \mathrm{C} \\
-1 \mathrm{~h}\end{array}$ & $2171 \pm 40 c$ & $21 \pm 1 b$ & $181 \pm 3.3 c$ & $\begin{array}{l}12.5 \pm \\
0.3 \mathrm{~b}\end{array}$ & $\begin{array}{l}105.7 \pm \\
3.8 b\end{array}$ & $\begin{array}{l}41.5 \pm \\
0.0081 \mathrm{c}\end{array}$ \\
\hline $\begin{array}{l}41^{\circ} \mathrm{C} \\
-1 \mathrm{~h}\end{array}$ & $997 \pm 25 d$ & $15 \pm 0.9 c$ & $83 \pm 2.1 d$ & $\begin{array}{l}14.2 \pm \\
0.4 a\end{array}$ & $\begin{array}{l}69.3 \pm \\
4.4 \mathrm{c}\end{array}$ & $\begin{array}{l}21 \pm \\
0.0073 d\end{array}$ \\
\hline $\begin{array}{l}45^{\circ} \mathrm{C} \\
-1 \mathrm{~h}\end{array}$ & $0 \pm 0 \mathrm{e}$ & $0 \pm 0 d$ & $0 \pm 0 \mathrm{e}$ & $0 \pm 0 \mathrm{~d}$ & $0 \pm 0 d$ & $0 \pm 0 e$ \\
\hline $\mathrm{CK}_{3}$ & $7780 \pm 33.1 \mathrm{a}$ & $51 \pm 2.0 a$ & $648 \pm 2.8 a$ & $\begin{array}{l}10.8 \pm \\
0.3 c\end{array}$ & $\begin{array}{l}155 \pm \\
6.1 \mathrm{a}\end{array}$ & $\begin{array}{l}90.7 \pm \\
0.0055 a\end{array}$ \\
\hline
\end{tabular}

Effects of short-time high temperature on the survival and development of Z.cucurbitae (Coquillett) $\left(F_{1}\right.$ generation)

The effects of short-time high temperature on the survival and development of Z.cucurbitae (Coquillett) ( $F_{1}$ generation) are shown in Table 6 . The survival rate decreased with increase in temperature. The survival rate of females in the same treatment was slightly higher than that of males. The survival rate of females in the $33^{\circ} \mathrm{C}$ treatment was the highest $(94.4 \%)$, and that of males in the $45^{\circ} \mathrm{C}$ treatment was the lowest (45.8\%), indicating that females were more resistant to high temperature than males. The lifespan shortened with increase in temperature. The longevity of females was longer than that of males in the same treatment. The longevity of females in the $33^{\circ} \mathrm{C}$ treatment was the longest (150d), and that of males in the $45^{\circ} \mathrm{C}$ treatment was the shortest (106d), both of which were significantly lower than that of the control. 
Table 6

Effects of short term high temperature on survival and development of Z. cucurbitae

(Coquillett) ( $F_{1}$ generation)

\begin{tabular}{|llll|}
\hline $\begin{array}{l}\text { Index } \\
\text { Dispose }\end{array}$ & \multicolumn{2}{c}{ Lifespan } & Survival rate \\
\hline $33^{\circ} \mathrm{C}-1 \mathrm{~h}$ & $\square$ & $150 \pm 3.6 \mathrm{bc}$ & $94.4 \pm 0.02 \mathrm{ab}$ \\
& $\square$ & $144 \pm 2.8 \mathrm{~cd}$ & $91.7 \pm 0.02 \mathrm{~b}$ \\
\hline $37^{\circ} \mathrm{C} 1 \mathrm{~h}$ & $\square$ & $141 \pm 5.9 \mathrm{~cd}$ & $90.3 \pm 0.01 \mathrm{~b}$ \\
\cline { 2 - 4 } & $\square$ & $136 \pm 5.4 \mathrm{~cd}$ & $87.5 \pm 0.02 \mathrm{bc}$ \\
\hline $41^{\circ} \mathrm{C}-1 \mathrm{~h}$ & $\square$ & $132 \pm 3.8 \mathrm{cde}$ & $80.6 \pm 0.02 \mathrm{~cd}$ \\
& $\square$ & $127 \pm 4.7 \mathrm{de}$ & $77.8 \pm 0.02 \mathrm{~d}$ \\
\hline $45^{\circ} \mathrm{C}-1 \mathrm{~h}$ & $\square$ & $113 \pm 2.9 \mathrm{ef}$ & $54.2 \pm 0.02 \mathrm{e}$ \\
& $\square$ & $106 \pm 1.5 \mathrm{f}$ & $45.8 \pm 0.03 \mathrm{f}$ \\
\hline $\mathrm{CK}_{1}$ & $\square$ & $180 \pm 5.4 \mathrm{a}$ & $100 \pm 0 \mathrm{a}$ \\
\hline & $\square$ & $167 \pm 3.6 \mathrm{ab}$ & $100 \pm 0 \mathrm{a}$ \\
\hline
\end{tabular}

Effects of short-term high temperature on the survival and development of Z.cucurbitae (Coquillett) $\left(F_{2}\right.$ generation)

The effects of short-time high temperature on the survival and development of Z.cucurbitae (Coquillett) $\left(F_{2}\right.$ generation) are shown in Table 7. The survival rate decreased with the increase in temperature. The survival rate of females in the same treatment was slightly higher than that of males. The highest survival rate of females in the $33^{\circ} \mathrm{C}$ treatment was $88.9 \%$, and the lowest survival rate of males in the $45^{\circ} \mathrm{C}$ treatment was $33.3 \%$, indicating that females were still more heat-resistant than males in the second high temperature treatment. But the survival rate was lower than that in the $F_{1}$ generation. The longevity decreased with increase in temperature and was lower than that of the $F_{1}$ generation. The longevity of females was longer than that of males in the same treatment. The longevity of females in the $33^{\circ} \mathrm{C}$ treatment was the longest (145d), and that of males in the $45^{\circ} \mathrm{C}$ treatment was the shortest (49d), both of which were significantly lower than that of the control. Pupa weight, pupation rate and emergence rate decreased with increase in temperature, and the lowest values recorded were $0.0067 \mathrm{~g}, 17.5 \%$ and $37.5 \%$ respectively at $45^{\circ} \mathrm{C}$, which were significantly lower than those of the control. The sex ratio increased with increase in temperature, and the maximum of $6: 1$ was recorded at $45^{\circ} \mathrm{C}$, indicating that females were more heat-resistant than males, which was consistent with the above mentioned survival rate and longevity of females compared with males. 
Table 7

Effects of short term high temperature on survival and development of Z. cucurbitae (Coquillett) $\left(F_{2}\right.$ generation)

\begin{tabular}{|c|c|c|c|c|c|c|c|}
\hline $\begin{array}{l}\text { Index } \\
\text { Dispos }\end{array}$ & & Lifespan & $\begin{array}{l}\text { Survival } \\
\text { rate }\end{array}$ & Pupae weight & $\begin{array}{l}\text { Pupation } \\
\text { rate }\end{array}$ & $\begin{array}{l}\text { Emergence } \\
\text { rate }\end{array}$ & $\begin{array}{l}\text { Sex } \\
\text { ratio }\end{array}$ \\
\hline \multirow{2}{*}{$\begin{array}{l}33^{\circ} \mathrm{C}- \\
1 \mathrm{~h}\end{array}$} & 口 & $145 \pm 2.7 b$ & $88.9 \pm 0.02 b$ & \multirow{2}{*}{$\begin{array}{l}0.0162 \pm \\
0.0002 b\end{array}$} & \multirow{2}{*}{$\begin{array}{l}82.5 \pm \\
0.011 \mathrm{~b}\end{array}$} & \multirow{2}{*}{$\begin{array}{l}86.0 \pm \\
0.024 \mathrm{~b}\end{array}$} & \multirow[t]{2}{*}{$1.43: 1$} \\
\hline & प & $\begin{array}{l}139 \pm \\
3.5 b c\end{array}$ & $86.1 \pm 0.02 b$ & & & & \\
\hline \multirow[t]{2}{*}{$\begin{array}{l}37^{\circ} \mathrm{C}- \\
1 \mathrm{~h}\end{array}$} & ૫ & $\begin{array}{l}132 \pm \\
4.0 \mathrm{bc}\end{array}$ & $68.1 \pm 0.03 c$ & \multirow[t]{2}{*}{$\begin{array}{l}0.0136 \pm \\
0.0002 c\end{array}$} & \multirow[t]{2}{*}{$\begin{array}{l}76.7 \pm \\
0.010 \mathrm{c}\end{array}$} & \multirow[t]{2}{*}{$\begin{array}{l}60.9 \pm \\
0.014 \mathrm{c}\end{array}$} & \multirow[t]{2}{*}{$1.55: 1$} \\
\hline & प & $\begin{array}{l}126 \pm \\
4.5 \mathrm{~cd}\end{array}$ & $\begin{array}{l}61.1 \pm \\
0.02 \mathrm{~cd}\end{array}$ & & & & \\
\hline \multirow[t]{2}{*}{$\begin{array}{l}41^{\circ} \mathrm{C}- \\
1 \mathrm{~h}\end{array}$} & प & $\begin{array}{l}110 \pm \\
1.7 \mathrm{de}\end{array}$ & $58.3 \pm 0.02 d$ & \multirow[t]{2}{*}{$\begin{array}{l}0.0103 \pm \\
0.0002 \mathrm{~d}\end{array}$} & \multirow[t]{2}{*}{$45 \pm 0.018 d$} & \multirow[t]{2}{*}{$51.7 \pm 0.022 c$} & \multirow[t]{2}{*}{$1.8: 1$} \\
\hline & प & $108 \pm 1.6 e$ & $54.2 \pm 0.02 d$ & & & & \\
\hline \multirow{2}{*}{$\begin{array}{l}45^{\circ} \mathrm{C}- \\
1 \mathrm{~h}\end{array}$} & प & $51 \pm 3.3 f$ & $36.1 \pm 0.02 \mathrm{e}$ & \multirow{2}{*}{$\begin{array}{l}0.0067 \pm \\
0.0008 \mathrm{e}\end{array}$} & \multirow{2}{*}{$\begin{array}{l}17.5 \pm \\
0.011 \mathrm{e}\end{array}$} & \multirow{2}{*}{$\begin{array}{l}37.5 \pm \\
0.042 d\end{array}$} & \multirow[t]{2}{*}{$6: 1$} \\
\hline & 0 & $49 \pm 3.3 f$ & $33.3 \pm 0.03 e$ & & & & \\
\hline \multirow[t]{2}{*}{$\mathrm{CK}_{2}$} & प & $173 \pm 3.6 a$ & $100 \pm 0 a$ & \multirow{2}{*}{$\begin{array}{l}0.0248 \pm \\
0.0001 \mathrm{a}\end{array}$} & \multirow{2}{*}{$\begin{array}{l}93.3 \pm \\
0.011 a\end{array}$} & \multirow{2}{*}{$\begin{array}{l}98.2 \pm \\
0.011 a\end{array}$} & \multirow[t]{2}{*}{$1.12: 1$} \\
\hline & प & $170 \pm 3.8 a$ & $100 \pm 0 a$ & & & & \\
\hline
\end{tabular}

Effects of short-time high temperature on the survival and development of Z.cucurbitae (Coquillett) $\left(F_{3}\right.$ generation)

The effects of short-time high temperature on the survival and development of Z.cucurbitae (Coquillett) $\left(\mathrm{F}_{3}\right.$ generation) are shown in Table 7. Pupa weight, pupation rate and emergence rate decreased with increase in temperature, and the lowest values recorded were $0.0037 \mathrm{~g}, 8.3 \%$ and $13.9 \%$ respectively at $45^{\circ} \mathrm{C}$, which were significantly lower than those of the control. The sex ratio increased with increase in temperature, and the maximum of $3: 1$ was recorded at $41^{\circ} \mathrm{C}$. All the females emerged at $45^{\circ} \mathrm{C}$, indicating that the females were more heat-resistant than the males. The survival rate decreased with increase in temperature. The survival rate of females in the same treatment was slightly higher than that of males. The highest survival rate of females $(63.9 \%)$ was recorded under $33^{\circ} \mathrm{C}$ and the lowest was under $45^{\circ} \mathrm{C}$. All of them died after high-temperature treatment, indicating that females were still more heat-resistant than males after multiple high-temperature treatments. However, the survival rate was lower than that of $F_{1}$ and $F_{2}$ generations. The longevity decreased with increase in temperature and was lower than that of the $F_{1}$ and $F_{2}$ generations in general. The longevity of females in the same treatment was longer than that of males. The longevity of females in the $33^{\circ} \mathrm{C}$ treatment was the longest ( 141 days), and that in $45^{\circ} \mathrm{C}$ treatment was the shortest (0 days), which were significantly lower than those in the control. 
Table 8

Effects of short term high temperature on survival and development of Z. cucurbitae (Coquillett) ( $F_{3}$ generation)

\begin{tabular}{|c|c|c|c|c|c|c|c|}
\hline $\begin{array}{l}\text { Index } \\
\text { Dispose }\end{array}$ & & Lifespan & Survival rate & Pupae weight & $\begin{array}{l}\text { Pupation } \\
\text { rate }\end{array}$ & $\begin{array}{l}\text { Emergence } \\
\text { rate }\end{array}$ & $\begin{array}{l}\text { Sex } \\
\text { ratio }\end{array}$ \\
\hline \multirow[t]{2}{*}{$\begin{array}{l}33^{\circ} \mathrm{C}- \\
1 \mathrm{~h}\end{array}$} & $\square$ & $141 \pm 1.6 b$ & $\begin{array}{l}63.9 \pm \\
0.02 \mathrm{~b}\end{array}$ & \multirow[t]{2}{*}{$\begin{array}{l}0.0156 \pm \\
0.0002 b\end{array}$} & \multirow[t]{2}{*}{$\begin{array}{l}61.7 \pm \\
0.011 \mathrm{~b}\end{array}$} & \multirow[t]{2}{*}{$\begin{array}{l}43.3 \pm \\
0.017 \mathrm{~b}\end{array}$} & \multirow[t]{2}{*}{$1.46: 1$} \\
\hline & $\square$ & $138 \pm 1.4 b c$ & $\begin{array}{l}59.7 \pm \\
0.01 \mathrm{bc}\end{array}$ & & & & \\
\hline \multirow[t]{2}{*}{$\begin{array}{l}37^{\circ} \mathrm{C}- \\
1 \mathrm{~h}\end{array}$} & $\square$ & $127 \pm 3.8 \mathrm{~cd}$ & $\begin{array}{l}54.2 \pm \\
0.02 \mathrm{~cd}\end{array}$ & \multirow[t]{2}{*}{$\begin{array}{l}0.0094 \pm \\
0.0003 c\end{array}$} & \multirow[t]{2}{*}{$\begin{array}{l}40.8 \pm \\
0.008 \mathrm{c}\end{array}$} & \multirow[t]{2}{*}{$\begin{array}{l}35.0 \pm \\
0.026 \mathrm{~b}\end{array}$} & \multirow[t]{2}{*}{$1.83: 1$} \\
\hline & $\square$ & $122 \pm 4.0 d$ & $\begin{array}{l}52.8 \pm \\
0.02 \mathrm{de}\end{array}$ & & & & \\
\hline \multirow[t]{2}{*}{$\begin{array}{l}41^{\circ} \mathrm{C}- \\
1 \mathrm{~h}\end{array}$} & $\square$ & $90.2 \pm 3.6 \mathrm{~d}$ & $\begin{array}{l}47.2 \pm \\
0.02 \mathrm{ef}\end{array}$ & \multirow[t]{2}{*}{$\begin{array}{l}0.0049 \pm \\
0.0006 \mathrm{~d}\end{array}$} & \multirow[t]{2}{*}{$\begin{array}{l}18.3 \pm \\
0.011 d\end{array}$} & \multirow[t]{2}{*}{$18.1 \pm 0.059 c$} & \multirow[t]{2}{*}{$3: 1$} \\
\hline & $\square$ & $88.7 \pm 3.5 d$ & $\begin{array}{l}43.1 \pm \\
0.01 f\end{array}$ & & & & \\
\hline \multirow{2}{*}{$\begin{array}{l}45^{\circ} \mathrm{C}- \\
1 \mathrm{~h}\end{array}$} & $\square$ & $0 \pm 0 \mathrm{e}$ & $0 \pm 0 \mathrm{~g}$ & \multirow{2}{*}{$\begin{array}{l}0.0037 \pm \\
0.0003 d\end{array}$} & \multirow{2}{*}{$\begin{array}{l}8.3 \pm \\
0.0516 \mathrm{e}\end{array}$} & \multirow{2}{*}{$\begin{array}{l}13.9 \pm \\
0.090 \mathrm{~d}\end{array}$} & \multirow[t]{2}{*}{$1: 0$} \\
\hline & $\square$ & $0 \pm 0 \mathrm{e}$ & $0 \pm 0 \mathrm{~g}$ & & & & \\
\hline \multirow[t]{2}{*}{$\mathrm{CK}_{3}$} & प & $183 \pm 3.5 a$ & $100 \pm 0 a$ & \multirow{2}{*}{$\begin{array}{l}0.0256 \pm \\
0.0001 \mathrm{a}\end{array}$} & \multirow{2}{*}{$\begin{array}{l}94.2 \pm \\
0.015 a\end{array}$} & \multirow{2}{*}{$\begin{array}{l}97.3 \pm \\
0.012 a\end{array}$} & \multirow[t]{2}{*}{$1.2: 1$} \\
\hline & 0 & $178 \pm 3.4 a$ & $100 \pm 0 a$ & & & & \\
\hline
\end{tabular}

\section{Discussion}

A variety of ecological models have been applied to study insect adaptation on a wide scale. Due to the different ecological theories and algorithms used for the models, the prediction results are different. For example, Kong et al. (2008) used CLIMEX and DIVA-GIS to predict and analyze the suitable areas of Z.cucurbitae (Coquillett), and the results showed that the whole of Australia was suitable for Z.cucurbitae (Coquillett). However, our results showed that only the northern part of Australia showed low suitability for Z.cucurbitae (Coquillett), Other areas were not suitable for the survival of Z.cucurbitae (Coquillett). The central and western regions of Australia are desert areas, and the high temperature and drought are not suitable for their survival Z.cucurbitae (Coquillett). This result proves that the prediction accuracy of the model used in this study was better than that obtained with the CLIMEX model. In addition, the research model used in our study requires the distribution data of species, and data on environmental variables which can be downloaded from the official website of WordClim. Therefore, the model can also be applied for the prediction of suitable areas for other species.

The impact of climate change on population development can be linear or non-linear (Grünig et al. 2020). When the response to the impact is not linear, the rate of change of population development is usually 
faster than that of linear change (Dakos et al. 2019). Large scale climate and niche conditions jointly affect the population development of Z.cucurbitae (Coquillett). Under These conditions may influence Z.cucurbitae (Coquillett) to suddenly erupt in areas that they did not occur previously. More seriously, other insects with similar climatic conditions to Z.cucurbitae (Coquillett) are likely to invade this area, thus aggravating the harm (Brockerhoff and Liebhold 2017). Therefore, in the context of global climate change, in addition to the impact of large-scale climate change on the development of insects and other biological populations, attention should also be paid to the outbreak of insect migration caused by niche climate change, especially in their non-occurring areas.

The growth, development, survival and reproduction of insects are regulated by temperature, it develops at different rates over different temperature ranges (Culos and Tyson 2014). The duration and frequency of high temperature in niche are important characteristics of heat effect (Ma et al. 2018; Zhu et al. 2019). Rapid temperature increase usually enhances insect metabolism and produces offspring, which enables rapid population development (Atkinson 1994; Cara et al. 2018; Tseng et al. 2019). In this study, it was found that after short-time high temperature treatment in small-scale habitat, the prophase of oviposition of Z.cucurbitae (Coquillett) adults in $\mathrm{F}_{1}$ and $\mathrm{F}_{2}$ generations was shortened with increase in temperature. Zhou (2016) observed the anatomy of the ovaries of the Z.cucurbitae (Coquillett) after high temperature treatment, and confirmed that high temperature accelerated ovarian development and promoted oviposition Z.cucurbitae (Coquillett). When the number of high temperature treatments increased, the oviposition behavior of Z.cucurbitae (Coquillett) was inhibited, and the prophase of their oviposition Z.cucurbitae (Coquillett) in the $F_{3}$ generation was prolonged. Gu et al. (2020) showed that the prophase of oviposition of Z.cucurbitae (Coquillett) was prolonged with increase in temperature after $34-42^{\circ} \mathrm{C}(12 \mathrm{~h})$ stress, which was consistent with the results of this study. High temperature accelerated the growth rate of Z.cucurbitae (Coquillett) and shortened their oviposition duration, but it was not conducive to their reproduction. Z.cucurbitae (Coquillett) The oviposition of the $F_{1}$ generation increased under exposure to $45^{\circ} \mathrm{C}$ for $1 \mathrm{~h}$. However, the total oviposition, daily egg production, single female oviposition and oviposition days of the other treatments were significantly lower than those of the control, and decreased with increase in temperature and treatment times. High temperatures were not conducive for the oviposition of Z.cucurbitae (Coquillett) generally. For example, the egg hatchability of the adults of Ophraella communai was decreased when treated at $40^{\circ} \mathrm{C}, 42^{\circ} \mathrm{C}$ and $44^{\circ} \mathrm{C}$ for $3 \mathrm{~h}$, compared to the control at $28^{\circ} \mathrm{C}$ (Chen et al. 2018). After the adults of Carposina sasakii was subjected to short-term high temperature stress, the spawning quantity gradually decreased with increase in temperature and treatment time (Li et al. 2014).

High temperatures can disrupt ion balance in insect cells (hyperkalemia), thereby impairing neurophysiological functions and damaging mitochondria (O 'Sullivan et al. 2017; Bowler 2018). They can also destroy the water retaining structure in insects, even if the wax layer and oil in the insect epidermis are liquefied, increase water loss, indirectly cause damage and lead to death due to drying in insects (Gibbs 2002; Chown et al. 2011). The results of this study showed that the survival rate and life span of Z.cucurbitae (Coquillett) decreased gradually with increase in temperature from $33^{\circ} \mathrm{C}$ to $45^{\circ} \mathrm{C}$. At the same temperature and with increase in the number of treatments (one treatment per generation), the 
survival rate and life span of Z.cucurbitae (Coquillett) decreased. That of the $\mathrm{F}_{3}$ generation Z.cucurbitae (Coquillett) could not survive after exposure to $45^{\circ} \mathrm{C}$ for $1 \mathrm{~h}$. He et al. (2019) subjected the adults of Assara inouei Yamanaka to short-term high temperature stress, and the results showed that the survival rate of adult gradually decreased and the life span gradually shortened with increase in temperature and treatment time, which is consistent with the results of this study. This indicates that the intensity, duration and frequency of high temperature are closely related to the survival and life span of insects.

The female adults of Z.cucurbitae (Coquillett) were more tolerant to short-time high temperature than the male adults as they had a higher survival rate and life span than that of male adults after short-time high temperature. Zhou (2016) conducted short-term high temperature and fluctuating high temperature treatment on the adults of Z.cucurbitae (Coquillett). The results showed that the survival rate and longevity of female adults were higher than that of males indicating that they were more heat-resistant than males, which was consistent with the results in this paper. Short-term high temperature treatment also affected the sex ratio (female/male) of the offspring of Z.cucurbitae (Coquillett), which increased with increase in temperature. The sex ratio of Z.cucurbitae (Coquillett) pupae emergence in the $45^{\circ} \mathrm{C}$ treatment group of the $F_{2}$ generation was the largest, which was 6: 1. Gu et al. (2020) found Z.cucurbitae (Coquillett) that after $12 \mathrm{~h}$ of high temperature treatment, the female ratio of offspring of Z.cucurbitae (Coquillett) adults gradually increased with the increase in treatment temperature. In this study, it was found that when the newly emerged adults of the $F_{2}$ generation underwent high temperature treatment, the adults of the offspring Z.cucurbitae (Coquillett) which emerged in the $45^{\circ} \mathrm{C}$ group of the $\mathrm{F}_{3}$ generation were all female adults with a sex ratio of 1:0. After two successive high temperature treatments, the number of $\mathrm{F}_{3}$ generation males of Z.cucurbitae (Coquillett) decreased or even could not complete emergence.

High temperatures not only affect contemporary adults, but also affect the next generation through "maternal effect". The results of this study showed that short-term high temperature treatment of Z.cucurbitae (Coquillett) adults resulted in decreased egg hatching rate, pupation rate and emergence rate of the next generation, increased sex ratio and decreased pupa weight, resulting in smaller offspring. The weight of pupae was also decreased when the larvae of Spodoptera mauritia and Heliothis virescens experienced continuous heat stress of $35^{\circ} \mathrm{C}$ (Ghazanfar et al. 2020). Heat damage can induce changes in insect body size, and rapidly increasing temperature usually increases insect metabolism, resulting in increased generation of offspring and rapid population development (Atkinson 1994; Cara et al. 2018; Tseng et al. 2018). Although smaller offspring individuals are more prone to dehydration and overheating (Gardner et al. 2011), small individuals may promote the absorption of water and nutrients by the insect gut or intestinal symbiotic bacteria to avoid heat damage (Kikuchi et al. 2016). However, there are few studies on insect growth trajectories and their potential physiological mechanisms under continuous short-term high temperature events. Therefore, a more systematic evaluation of the effects of short-time high temperature on the population of Z.cucurbitae (Coquillett) needs to be further studied.

When insects are stimulated by certain environmental conditions such as high temperature, they will produce "toxic excitatory effect", which is a special survival coping strategy of temperature adaptation. It 
is also considered a survival strategy against high temperature stress (Villalpando et al. 2008; Zhang et al. 2013; $\mathrm{Ma}$ et al. 2016). In this study, the oviposition of the $\mathrm{F}_{1}$ generation Z.cucurbitae (Coquillett) exposed to $45^{\circ} \mathrm{C}$ for $1 \mathrm{~h}$ was significantly higher than that of the control. A similar phenomenon was also observed for Bactocera dorsalis (Hendel). The oviposition of female B. dorsalis (Hendel) exposed to $35^{\circ} \mathrm{C}$ for $2 \mathrm{~h}$ showed a decrease compared to that of the control $\left(25^{\circ} \mathrm{C}\right)$, while oviposition of that exposed under $40^{\circ} \mathrm{C}$ for $2 \mathrm{~h}$ was 1445.4 eggs / $\mathrm{d}$, which was significantly higher than that of the control (691.89 eggs / d) (Ren et al. 2010). Zhou (2016) found that the frequency of copulation and oviposition of Z.cucurbitae (Coquillett) increased after exposure to $45^{\circ} \mathrm{C}$ for $1 \mathrm{~h}$, but the "toxic excitatory effect" Z.cucurbitae (Coquillett) was unstable, and was no longer effective when the treatment duration was prolonged. The results of our study showed that there was no increase in oviposition after the $F_{2}$ and $F_{3}$ generations were subjected to $45^{\circ} \mathrm{C}$ for $1 \mathrm{~h}$, and the "toxic excitatory effect" was difficult to reproduce between different generations. This indicate that "toxic excitatory effect" was not only affected by the duration of high temperature treatment, but also by the number of high temperature treatments. This proved again that the "toxic excitatory effect" was unstable. Therefore, the intensity, duration and frequency of high temperature in the field should be fully considered in the control of Z.cucurbitae (Coquillett) during the high temperature season. Also, these characteristics of short-term high temperatures can also be used for the control of Z.cucurbitae (Coquillett).

The distribution of species is also affected by its own dispersal capacity, human factors, geographical barriers, and interactions among species. The normal development of Z.cucurbitae (Coquillett) is not only affected by temperature, but also restricted by environmental factors such as humidity and rainfall (Li et al. 2016; He et al. 2019). In this study, precipitation in the wettest month (bio13), precipitation in the driest month (bio14), annual mean temperature (bio1), monthly mean diurnal temperature difference (bio2) and precipitation in the warmest season (bio18) were the most influential environmental factors to the suitable area of Z.cucurbitae (Coquillett). The results indicated that temperature and humidity were important to their normal growth and development Z.cucurbitae (Coquillett). For example, Egypt, Syria and other places are located near $30^{\circ}$ north latitude, and the temperature conditions in these areas can meet the growth and development of Z.cucurbitae (Coquillett). Under normal circumstances, these areas can be suitable for Z.cucurbitae (Coquillett). However, due to the dry climate and low annual precipitation in these areas, Z.cucurbitae (Coquillett) cannot survive here. In this study, the effects of niche temperature on the population development of Z.cucurbitae (Coquillett) were analyzed. The effects of other environmental factors on thire population development Z.cucurbitae (Coquillett) can be further studied.

\section{Declarations}

\section{Author Contributions}

YYL, AQW, BZ, SHP and SHZ participated in the study design and analysis the manuscript. HMY and JLL, participated in study design and helped to draft the manuscript. Supervision and financially support, SHZ, Revised and processed. All authors read and approved the final manuscript. 


\section{Acknowledgements}

This study was supported by High-level Talent Project of Hainan Natural Science Foundation (320RC499), Key R\&D Projects of Hainan Province(ZDYF2019096), Hainan Provincial Association for Science and Technology Youth Science and Technology Talents Academic Innovation Program Project (QCXM201908), Natural Science Foundation of China (31760518), The Open Project of Key Laboratory of Tropical Fruit Tree Biology of Hainan Province (KFZX2020001).

\section{References}

Atkinson D (1994) Temperature and organism size: a biological law for ectotherms? Adv Ecol Res 25:158. https://doi.org/10.1016/S0065-2504(08)60212-3

Bale JS, Masters GJ, Hodkinson ID (2002) Herbivory in global climate change research: direct effects of rising temperature on insect herbivores. Glob Change Biol 8(1):1-16. https://doi.org/10.1046/j.13652486.2002.00451.x

Bowler K (2018) Heat death in poikilotherms: Is there a common cause? J Therm Biol 76:77-79. https://doi.org/10.1016/j.jtherbio.2018.06.007

Brockerhoff EG, Liebhold AM (2017) Ecology of forest insect invasions. Biol Invasions 19(11):31413159. https://doi.org/10.1007/s10530-017-1514-1

Cara Donna PJ, Cunningham JL, ller AM (2018) Experimental warming in the field delays phenology and reduces body mass, fat content and survival: implications for the persistence of apollinator under climate change. Funct Ecol 32(10):2345-2356. https://doi.org/10.1111/1365-2435.13151

Chen HS, Zheng XW, Luo M, Guo JY, Solangi GS, Wan FH, Zhou ZH (2018) Effect of short-term hightemperature exposure on the life history parameters of Ophraella communa. Sci Rep 8(1):139-169. https://doi.org/10.1038/s41598-018-32262-z

Chen Y, Ma CS (2010) Effect of global warming on insect: a literature review. Acta Ecol Sin 30(8):21592172

Chown SL, Sorensen JG, Terblanche JS (2011) Water loss in insects: an environment-al change perspective. J Insect Physiol 57(8):1070-1084. https://doi.org/10.1016/j.jinsphys.2011.05.004

Culos GJ, Tyson RC (2014) Response of poikilotherms to thermal aspects of climate change. Ecological Complexity 20:293-306. https://doi.org/10.1016/j.ecocom.2014.09.003

Dakos Vasilis, Matthews Blake, Hendry Andrew P, Levine Jonathan, Loeyille Nicolas,Norberg Jon, Nosil Patrik, Scheffer Marten, De Meester Luc (2019) Ecosystem ti-pping points in an evolving world. Nature ecology \& evolution 3(3):355-362. https://doi.org/10.1038/s41559-019-0797-2 
Dhillon MK, Singh Ram, Naresh JS, Sharma HC (2005) The melon fruit fly, Bactro-cera cucurbitae: A review of its biology and management. Journal of Insect Science 5(1):40.

https://doi.org/10.1093/jis/5.1.40

Du Y, Ma CS, Zhao QH, Yang HP (2007) Effects of heat stress on physiological and biochenmical mechanisms of insects: a literature review. Acta Ecologica Sinica (4):1565-1572

Gardner JL, Peters A, Kearney MR, Leo J, Heinsohn Robert (2011) Declining body size: a third universal response to warming? Trends Ecol Evol 26(6):285-291. https://doi.org/10.1016/j.tree.2011.03.005

Ghazanfar MU, Hagenbucher S, Romeis J, Grabenweger Giselher M Michael (2020) Fluctuating temperatures influence the susceptibility of pest insects to biological control agents. J Pest Sci 93(3):1007-1018. https://doi.org/10.1007/s10340-020-01215-9

Gibbs AG (2002) Lipidmelting and cuticular permeability: New insights into an old problem. J Insect Physiol 48(4):391-400. https://doi.org/10.1016/S0022-1910(02)00059-8

Grünig M, Pierluigi C, Dominique M, Pellissier Loïc (2020) Inflection point in climatic suitability of insect pest species in Europe suggests non-linear responses to climate change. Global change biology 26(11):6338-6349. https://doi.org/10.1111/gcb.15313

Gu XP, Huang YY, Zhang JY, Chen GH (2020) Effects of short-term high-temperature stress on growth, development and reproduction of melon fly. Journal of Environmental Entomology 42(2):391-399

He C, Kong Q, Yuan SY, Shen RD, Xie K, Wang CM (2019) Effects of Temperature and Relative Humidity Stress on the Survival and Fecundity of the Melon Fly. Northern Horticulture (15):36-43

He C, Shen DR, Bai LX, Yi LH, Zhang R, Yuan SY, Tian XJ (2019) Effects of Short-term High-temperature Exposure on Surviva and Reproduction of Adult Assara inouei Yamanaka. Fujian Journal of Agricultural Sciences 34(10):1185-1191

He Q, Zhao R, Zhu Z (2020) Geographical distribution simulation and comparative analysis of Carpinus viminea and C. Iondoniana. Global Ecology Conservation 21:e00825.

https://doi.org/10.1016/j.gecco.2019.e00825

Hoffmann AA, Sgrò CM (2011) Climate change and evolutionary adaptation. Nature 470(7335):479-485. https://doi.org/10.1038/nature09670

IPCC Climate Change in 2013: The Physical Science Basis. Cambridge \& New York: Cambridge University Press $1-1552$

Jiang CM (2005) The population system and integrate quarantine and management of melon fly. Fujian Agricultural and Forestry University 
Jiang FZ, Zheng LY, Guo JX, Zhang GR (2015) Effects of temperature stress on insect fertility and its physiological and biochemical mechanisms. Acta Environmental Entomology 37(3):653-663

Kikuchi Y, Tada A, Musolin DL, Hari N, Hosokawa T, Fujisaki K, Fukatsu T (2016) Collapse of insect gut symbiosis under simulated climate change. MBio 7(5):e01578-e01516.

https://doi.org/10.1128/mBio.01578-16

Kong LB, Lin W, Li ZH, Wang FH, Wang ZL, Huang GS (2008) A Prediction of potential geographic distribution of melon fruit fly based on CLIMEX and DIVA-GIS. Journal of Plant Protection (2):148-154

Li DX, Lei XH, Xu YC, Li Z, Gao LW (2014) Effects of brief exposure to high temperature on the growth,development and reproduction of the peach fruit moth, Carposina sasakii (Lepidoptera: Carposinidae). Acta Entomologica Sinica 57(2):218-225

Li L, Ma HB, Niu LM, Zhang FP, Han DY, Chen JY, Fu YG (2016) Effects of habitats and climaticc factors on the quantitative dynamics of male Bactrocera cucurbita (Coquillett). Environ Entomol 38(4):766-770

Li WD, Xiao Q, Ai HM, Chen SL, Zhou WC (2008) The effective accumulated temperature and annual number of generation of melon fly, Bactrocera Cucurbitae Coquillett, in China. Journal of East China Entomology 17(3):188-193

Lobo JM (2016) The use of occurrence data to predict the effects of climate change on insects. Current Opinion in Insect Science 17:62-68. https://doi.org/10.1016/j.cois.2016.07.003

Ma CS, Wang L, Zhang W, Rudolf Volker HW (2018) Resolving biological impa-cts of multiple heat waves: interaction of hot and recovery days. Oikos 127(4):622-633. https://doi.org/10.1111/oik.04699

Ma G, Ma CS (2016) The impacts of extreme high temperature on insect populations under climate change: a review. Sci Sinica 46(5):556-564. https://doi.org/10.1360/N052016-00037

Moreno-Amat E, Mateo RG, Nieto-Lugilde D, Morueta-Holme Naia, Jens-Christian S, García-Amorena I (2015) Impact of model complexity on cross-temporal transferability in Maxent species distribution models: An assessment using paleobotanical data. Ecol Model 312:308-317.

https://doi.org/10.1016/j.ecolmodel.2015.05.035

O'Sullivan J, MacMillan HA, Overgaard J (2017) Heat stress is associated with disru-ption of ionbalance in the migratory locust, Locusta migratoria. Journal of Thermal Biology 68(Pt B):177-185. https://doi.org/10.1016/j.jtherbio.2016.04.001

Pecl GT, Araújo MB, Bell JD, Blanchard J, Bonebrake TC, Chen IC, Williams SE (2017) Biodiversity redistribution under climate change: Impacts on ecosystems and human well-being. Science 355(6332). https://doi.org/10.1126/science.aai9214 
Ren L, Lu YY, Liang GW, Zeng Q (2010) Study on the northward expansion trend of Bactrocera dorsalis based on response to environmental stress. The Third National Congress on Biological Invasions 53-54

Rozhnov VV, Pshegusov RH, Hernandez Blanco JA, Chistopolova MD, Pkhitik-ov AB, Trepet SA, Dronova NA, Naidenko SV, Yachmennikova AA (2021) MaxEnt Modeling for Predicting Suitable Habitats in the North Caucasus (Russian Part) for Persian Leopard (P. p. ciscaucasica) Based on GPS Data from Collared and Released Animals. Izvestiya Atmospheric Oceanic Physics 56(9):1090-1106.

https://doi.org/10.1134/S0001433820090212

Stefan R, Dim C (2011) Increase of extreme events in a warming world. Proceedings of the National Academy of Sciences 108(44):17905-17909. https://doi.org/10.1073/pnas.1101766108

Sunil K, Jim G, Amanda MW, Paul HE (2014) Using dist-rict-level occurrences in MaxEnt for predicting the invasion potential of an exotic inse-ct pest in India. Comput Electron Agric 103(2):55-62.

https://doi.org/10.1016/j.compag.2014.02.007

Tseng M, Kaur KM, Pari SS, Karnjit S, Denessa C, Christine HY, Paula P, Anmol T, Harpawantaj ST, Katrina $F(2018)$ Decreases in beetle body size linked to climate change and warming temperatures. J Anim Ecol 87(3):647-659. https://doi.org/10.1111/1365-2656.12789

Van dKCJ, Kevan PG, Koski MH (2019) The thermal ecology of flowers. Ann Bot 124:343-353. https://doi.org/10.1093/aob/mcz073

Villalpando SN, Williams RS, Norby RJ (2008) Elevated air temperature alters an old-field insect community in a multifactor climate change experiment. Glob Change Biol 15(4):930-942. https://doi.org/10.1111/j.1365-2486.2008.01721.x

Wang YS, Wang ZH, Xing HF, Li JW, Sun S (2019) Prediction of potential suitable distribution of Davidia involucrate Baill in China based on MaxEnt. Chin J Ecol 38(4):1230-1237

Wei SD, Huang SS, Wang YQ, Zeng DQ, Ling Y (2011) Effect of temperature on the development and reproduction of Bactrocera cucurbitae (Coquillett) population. Journal of Southern Agriculture 42(7):744747

Wu J (2008) Effect of heat stress on the growth and parasitic behavior of Trichogramma chilonis Ishii. Shihezi University

Yang RF (2013) Study on the lethal effect of Sitobion avenae (Fabricius) by high-temperature-short-time. Chinese Academy of Agricaltural Sciences Dissertation

Yuan SY, Kong Q, Li ZY, Xiao C, Chen B, Zhang GD (2005) Study on biology of Bactrocera (Zeugodacus) cucurbitae. Acta Agriculturae Boreali-occidentalis Sinica (3):43-45, 67 
Zeng B, Zhu W, Fu Y, Zhou S (2019) Response Mechanism of Oviposition and Rel-evant Protein Expression of Bactrocera cucurbitae (Coquillet) to Short-Term High-Tem-perature Conditions. Neotrop Entomol 48(2):197-206. https://doi.org/10.1007/s13744-018-0638-z

Zeng B, Zhu W, Fu Y (2018) Influence of high-temperature exposure on the mating, oviposition and thermotaxis of Bactrocera cucurbitae (Coquillet) (Diptera: Tephritidae). PLos One 13(9):e0204065. https://doi.org/10.1371/journal.pone.0204065

Zhang W, Zhao F, Hoffmann AAA (2013) single hot event that does not affect survival but decreases reproduction in the diamondback moth, Plutella xylostella. Plos One 8(10):e75923.

https://doi.org/10.1371/journal.pone.0075923

Zhou SH (2016) Studies on the responses of Bactrocera cucurbitae to high temperature stress and its molecular basis. Hainan University

Zhou ZS, Guo JY, Luo M, Wan FH (2011) Effect of short-term high temperature st-ress on the development and fecundity of Ophraella communa (Coleoptera: Chrysomeli-dae). Biocontrol Sci Tech 21(7):809-819. https://doi.org/10.1080/09583157.2011.584611

Zhu L, Wang L, Ma CS (2019) Sporadic short temperature events cannot be neglected in predicting impacts of climate change on small insects. J Insect Physiol 112:48-56.

https://doi.org/10.1016/j.jinsphys.2018.12.003

\section{Figures}

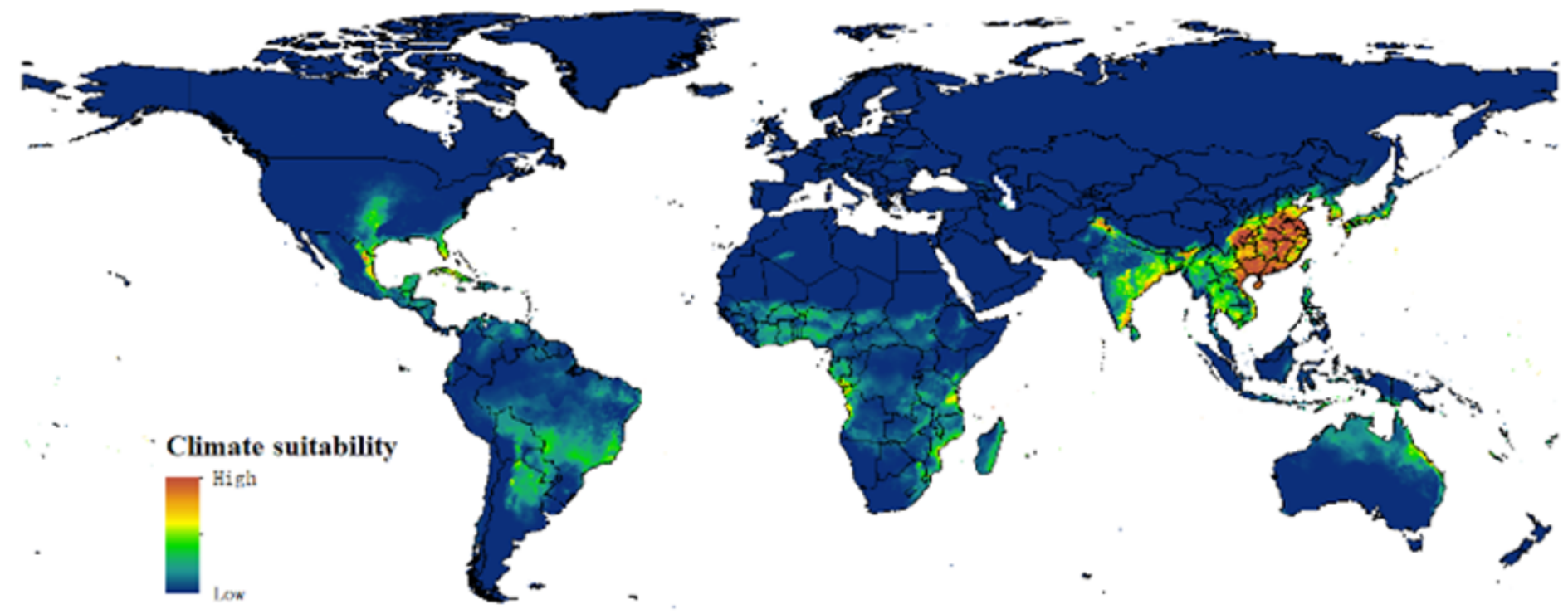

Figure 1 
Potential distribution of Z. cucurbitae (Coquillett) worldwide under current climatic conditions
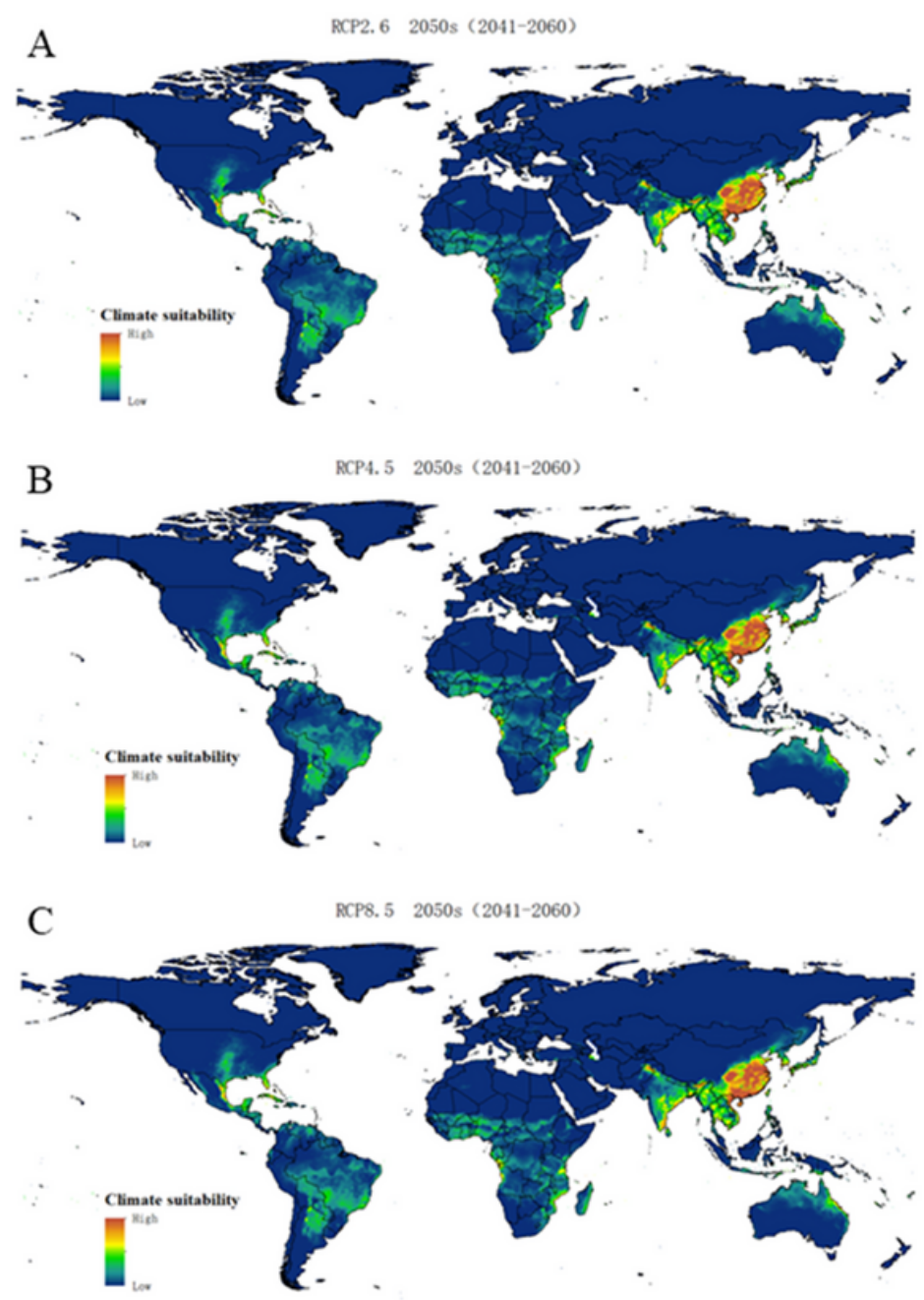

Figure 2

Distribution of Z.cucurbitae (Coquillett) in the global suitable area under climate conditions in 2050. (A. Suitable areas under RCP2.6;B. Suitable areas under RCP4.5;C. Suitable areas under RCP8.5) 